\title{
Zinc Modulates Bidirectional Hippocampal Plasticity by Effects on NMDA Receptors
}

\author{
Yukitoshi Izumi, ${ }^{1}$ Yves P. Auberson, ${ }^{2}$ and Charles F. Zorumski ${ }^{1,3}$ \\ Departments of ${ }^{1}$ Psychiatry and ${ }^{2}$ Neurobiology, Washington University School of Medicine, St. Louis, Missouri 63130, and ${ }^{3}$ Department of Chemistry, \\ Neuroscience, Novartis Institutes for BioMedical Research, CH-4002 Basel, Switzerland
}

Zinc has complex effects on NMDA receptors (NMDARs) and may be an endogenous modulator of synaptic plasticity. In the CA1 region of rat hippocampal slices, we observed that low micromolar concentrations of zinc depress NMDAR synaptic responses by $40-50 \%$ and inhibit long-term depression (LTD) but not long-term potentiation (LTP). A combination of zinc plus ifenprodil, an inhibitor of NR1/ NR2B receptors, produced no greater inhibition of synaptic NMDARs than either agent alone, suggesting overlapping effects on NMDARs. Similar to low micromolar zinc, ifenprodil inhibited LTD but not LTP. In contrast, low concentrations of 2-amino-5phosphonovalerate (APV) did not block either LTP or LTD despite producing $>50 \%$ inhibition of synaptic NMDARs. NVP-AAM077 ([(R)-[(S)-1-(4-bromo-phenyl)-ethylamino]-(2,3-dioxo-1,2,3,4-tetrahydro-quinoxalin-5-yl)-methyl]phosphonic acid), an antagonist with relative NR1/NR2A selectivity at low concentrations, also inhibited synaptic NMDARs by $\sim 50 \%$ at $0.05 \mu \mathrm{m}$ but failed to completely block either LTP or LTD. These results suggest that LTD induction depends on specific NMDARs with sensitivity to low micromolar zinc and ifenprodil, but LTP is less dependent on specific NMDAR subtypes. Because high-affinity sites of NR2A are likely occupied by ambient zinc, we also examined effects of extracellular zinc chelators. Zinc chelation blocked LTP but had no effect on LTD. This LTP inhibition was overcome by APV and NVP-AAM077 but not ifenprodil, suggesting that zinc chelation unmasks tonic NR1/NR2A activation that negatively modulates LTP.

Key words: LTP; LTD; ifenprodil; NMDA receptors; synaptic plasticity; metaplasticity

\section{Introduction}

NMDA receptors (NMDARs) participate in long-term potentiation (LTP) and long-term depression (LTD) in the CA1 hippocampal region (Malenka and Bear, 2004). Although NMDARs are heterogeneous with multiple subclasses (Cull-Candy and Leszkiewicz, 2004; Mayer and Armstrong, 2004), it is unclear whether the same NMDAR subtypes are involved in different forms of synaptic plasticity (Hrabetova et al., 2000). In CA1, deletion of specific NMDAR subunits alters the induction of LTP and LTD (Sakimura et al., 1995; Kutsuwada et al., 1996). Studies using antagonists with specificity for NMDAR subtypes suggest that receptors expressing NR1/NR2A and NR1/NR2B contribute differentially to bidirectional plasticity. Initial work using the NR1/NR2A antagonist NVP-AAM077 ([ $R$ )-[(S)-1-(4-bromophenyl)-ethylamino]-(2,3-dioxo-1,2,3,4-tetrahydro-quinoxalin5 -yl)-methyl]phosphonic acid) and the NR1/NR2B antagonists ifenprodil and Ro25-6981 $[R-(R, S)-\alpha$-(4-hydroxyphenyl)- $\beta$ methyl-4-(phenylmethyl)-1-piperidine propranol] indicated that LTP requires NR1/NR2A but not NR1/NR2B receptors (Liu et al.,

Received March 23, 2006; revised May 31, 2006; accepted June 1, 2006.

This work was supported by National Institutes of Health Grants AA12951, AG18434, and MH45493 and the Bantly Foundation. We are grateful to Novartis Pharm (Basal, Switzerland) for the gift of NVP-AAM077.

Correspondence should be addressed to Dr. Charles F. Zorumski, Department of Psychiatry, Washington University School of Medicine, 660 South Euclid Avenue, St. Louis, M0 63110. E-mail: zorumsk@@wustl.edu. DOI:10.1523/JNEUROSCI.1258-06.2006

Copyright $\odot 2006$ Society for Neuroscience $\quad$ 0270-6474/06/267181-08\$15.00/0
2004; Massey et al., 2004). Subsequent studies have questioned the NR1/NR2A specificity of NVP-AAM077 (Neyton and Paoletti, 2006) and found that LTP induction does not require specific NMDA receptor subclasses (Berberich et al., 2005; Weitlauf et al., 2005). Inhibitors of NR1/NR2B receptors, however, have consistently blocked LTD induction (Liu et al., 2004; Massey et al., 2004).

Zinc is an endogenous NMDAR antagonist (Westbrook and Mayer, 1987). Despite having clear effects on NMDARs, it is unknown whether zinc blocks LTP or LTD through actions on NMDARs. Xie and Smart (1994) found that $100 \mu \mathrm{M}$ zinc blocks LTP in both CA1 and CA3 regions of hippocampal slices. These authors concluded that LTP inhibition may not result simply from effects on NMDARs because induction of LTP at mossy fiber synapses in CA3 does not require NMDARs (Harris and Cotman, 1986). NMDAR subtypes have distinct sensitivities to zinc. Recombinant receptors expressing NR1/NR2B are blocked by low micromolar concentrations of zinc, but receptors containing NR1/NR2A have high- and low-affinity sites for inhibition (Grimwood et al., 1996; Williams, 1996; Chen et al., 1997; Paoletti et al., 1997; Choi and Lipton, 1999). High-affinity block of NR1/NR2A receptors occurs at low nanomolar concentrations, whereas lower-affinity inhibition requires concentrations in the $30-100 \mu \mathrm{M}$ range. This raises the possibility that zinc could differentially modulate LTP and LTD if these forms of plasticity are mediated by distinct NMDAR subclasses. Given the nanomolar levels of free zinc in brain extracellular fluid (Frederickson, 1989; Frederickson et al., 2006), it appears likely that high-affinity NR1/ 
NR2A sites are significantly occupied at baseline, suggesting that low micromolar concentrations of zinc act primarily on NR1/NR2B sites. We tested this by examining the effects of exogenous zinc on NMDAR-mediated synaptic responses and the induction of LTP and LTD in the CA1 region of rat hippocampal slices. We also compared zinc with NMDAR subtype-selective antagonists and to 2-amino-5-phosphonovalerate (APV), an antagonist with less subtype selectivity (Mishina et al., 1993; Buller et al., 1994; Priestley et al., 1995). To determine whether high-affinity NR1/NR2A inhibition modulates synaptic function, we examined effects of extracellular zinc chelators on synaptic NMDARs and plasticity.

\section{Materials and Methods}

Sprague Dawley rats ( $30 \pm 2 \mathrm{~d}$ old) were anesthetized with halothane and decapitated. Hippocampi were rapidly dissected, placed in artificial CSF (ACSF) (in mM: $124 \mathrm{NaCl}, 5 \mathrm{KCl}, 2$ $\mathrm{MgSO}_{4}, 2 \mathrm{CaCl}_{2}, 1.25 \mathrm{NaH}_{2} \mathrm{PO}_{4}, 22 \mathrm{NaHCO}_{3}$, and 10 glucose), gassed with $95 \% \mathrm{O}_{2}-05 \% \mathrm{CO}_{2}$ at $4-6^{\circ} \mathrm{C}$, and sliced transversely into $500 \mu \mathrm{m}$ slices using a vibratome. Slices were prepared from the septal half of the hippocampus and were placed in an incubation chamber containing gassed ACSF for $1 \mathrm{~h}$ at $30^{\circ} \mathrm{C}$. At the time of study, slices were transferred individually to a submersion recording chamber. Experiments were done at $30^{\circ} \mathrm{C}$. Drugs were dissolved in the ACSF and administered by bath perfusion at a rate of $2 \mathrm{ml} / \mathrm{min}$.

Extracellular recordings were obtained from the apical dendritic region for analysis of population EPSPs using $2 \mathrm{~m} \mathrm{NaCl}$ glass electrodes with resistances of 5-10 $\mathrm{M} \Omega$. Evoked synaptic responses were elicited with $0.1 \mathrm{~ms}$ constant current pulses through a bipolar electrode in the Schaffer collateral pathway. Synaptic responses in CA1 were monitored by applying single stimuli every $60 \mathrm{~s}$ at an intensity sufficient to elicit 50\% maximal EPSPs. After establishing a stable baseline for at least $10 \mathrm{~min}$ and a control input-output (IO) curve, LTP was induced by applying high-frequency stimulation (HFS) consisting of a single $100 \mathrm{~Hz}, 1 \mathrm{~s}$ stimulus train using pulses of the same amplitude. After the tetanus, responses were monitored every $60 \mathrm{~s}$. LTD was induced using a low-frequency stimulus train consisting of 900 single pulses at $1 \mathrm{~Hz}$.

Isolated NMDAR synaptic responses were studied in an extracellular solution containing 2 mM calcium and $0.1 \mathrm{~mm}$ magnesium. 6,7-Dinitroquinoxaline-2,3-dione (DNQX) was added to this solution at $30 \mu \mathrm{M}$ to inhibit AMPA receptormediated EPSPs, and responses were evoked once per minute. EPSPs were analyzed by measuring their rising slopes.

DNQX was obtained from Tocris Cookson (Ellisville, MO), and NVPAAM077 was a generous gift from Novartis Pharma (Basal, Switzerland). Other chemicals were purchased from Sigma (St. Louis, MO). Results in the text and figures represent means \pm SEM. Statistical significance was determined using Student's $t$ test when appropriate or the Mann-Whitney $U$ test with $p<0.05$. Statistical analyses were performed using SigmaStat (Jandel Scientific, San Rafael, CA).

A

B

C
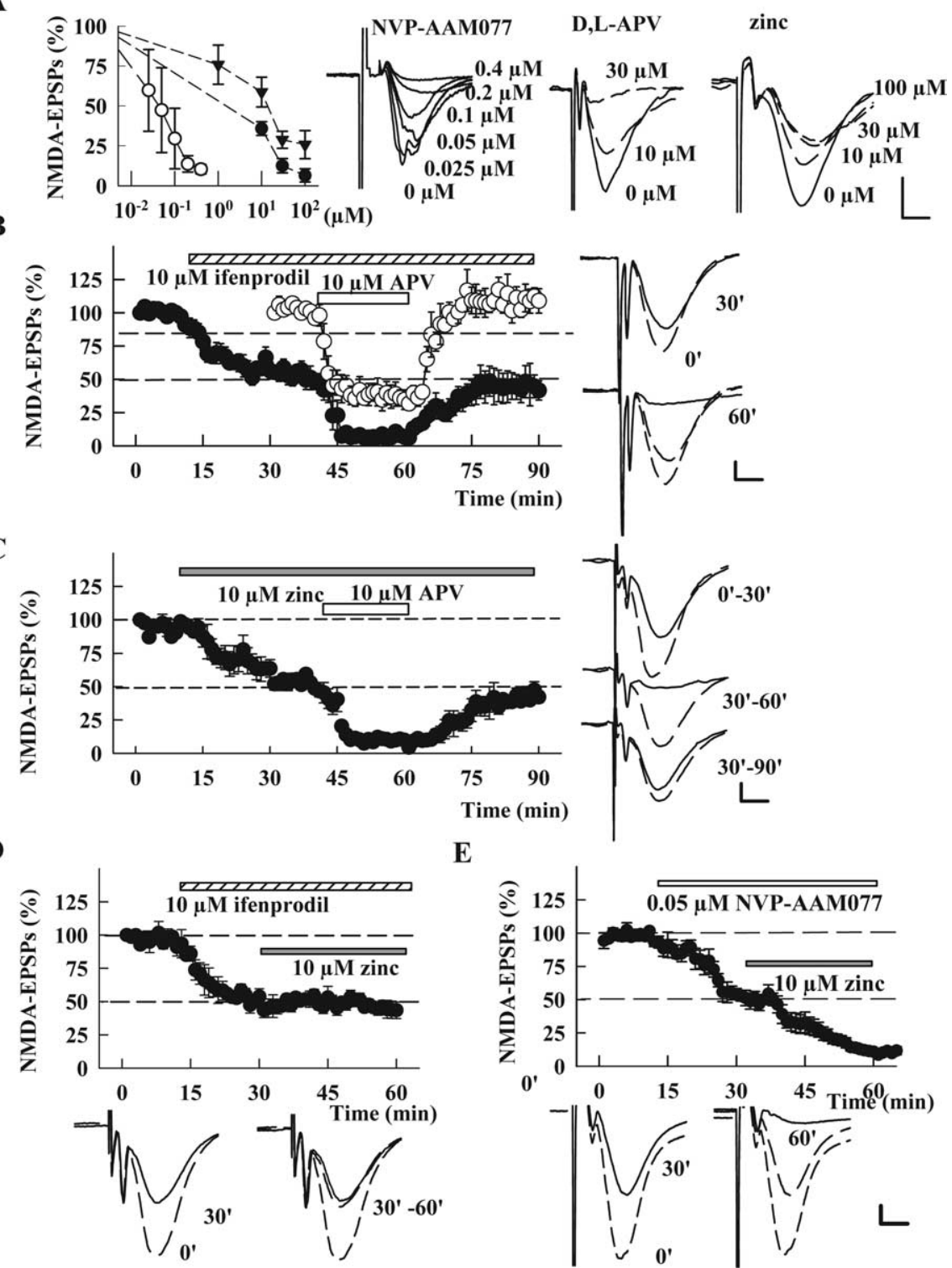

$\mathbf{E}$

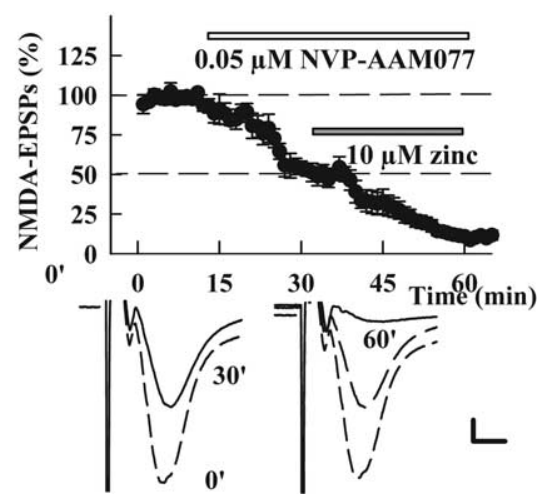

Figure 1. Effects of antagonists on NMDAR EPSPs. A, NVP-AAM077 (white circles), D,L-APV (black circles), and zinc (black triangles) inhibited NMDAR EPSPs in a concentration-dependent manner. Traces to the right show representative responses from slices treated with these antagonists. $\boldsymbol{B}$, Ifenprodil ( $10 \mu \mathrm{m}$; hatched bar) depressed NMDAR EPSPs by $\sim 50 \%$. Application of $10 \mu \mathrm{m}$ D, L-APV (white bar) in the presence of ifenprodil caused nearly complete depression (black circles). In the absence of ifenprodil, 10 $\mu M \mathrm{D}, \mathrm{L}-\mathrm{APV}$ only partially depressed NMDAR EPSPS (white circles). Traces to the right show a control response and the effects of APV (top) and ifenprodil alone and with APV (bottom). Numbers on the traces denote the time when traces were sampled. C, Zinc at $10 \mu \mathrm{m}$ (gray bar) also partially inhibited NMDAR EPSPs. Addition of $10 \mu \mathrm{M}$ APV (white bar) further suppressed these responses. Traces to the right show a control response and the effects of zinc alone and APV plus zinc. D, Addition of $10 \mu \mathrm{m}$ zinc (gray bar) to $10 \mu \mathrm{m}$ ifenprodil (hatched bar) did not further suppress NMDAR EPSPs. Traces below show inhibition by ifenprodil and the failure of zinc to cause additional inhibition in the presence of ifenprodil. $\boldsymbol{E}$, After administration of $0.05 \mu \mathrm{M}$ NVP-AAM077 (white bar), 10 $\mu \mathrm{m}$ zinc (gray bar) further depressed NMDAR EPSPs. Traces show representative waveforms. Calibration: $1 \mathrm{mV}, 5 \mathrm{~ms}$ for all.

\section{Results}

We initially examined the effects of zinc and several selective NMDAR antagonists on NMDAR-mediated EPSPs evoked by stimulation of the Schaffer collateral pathway. Exogenous zinc depressed NMDAR EPSPs in a concentration-dependent manner (Fig. $1 A$ ), with $10 \mu \mathrm{M}$ zinc producing $41.3 \pm 9.7 \%$ inhibition (Fig. 1C). The effects of zinc on NMDAR EPSPs are unlikely to result from presynaptic actions because zinc had no effect on EPSPs mediated by AMPA receptors $(+1.6 \pm 3.0 \%$ change with $100 \mu \mathrm{m}$ zinc; $n=4$ ) or on paired-pulse facilitation of field EPSPs 
$(+5.6 \pm 2.6 \%$ change in paired-pulse facilitation with $100 \mu \mathrm{M}$ zinc; $n=4$ ). The lack of effect on AMPA receptor EPSPs also makes it unlikely that the block of NMDAR EPSPs results from disinhibition caused by block of $\mathrm{GABA}_{\mathrm{A}}$ receptors (Westbrook and Mayer, 1987). Moreover, the inhibition of NMDAR EPSPs by zinc was not altered by $100 \mu \mathrm{M}$ picrotoxin, a $\mathrm{GABA}_{\mathrm{A}}$ receptor antagonist $(-42.8$ and $-66.2 \%$ change by 10 and $100 \mu \mathrm{M}$ zinc; $n=2$ each).

We compared the effects of zinc with other NMDAR antagonists, including agents that are selective for NMDAR subtypes. Ifenprodil, an inhibitor of NR1/NR2B-containing receptors (Williams, 1993; Priestley et al., 1995), depressed NMDAR EPSPs by $\sim 50 \%$ at $10 \mu \mathrm{M}$ (Fig. $1 B$ ). A similar degree of inhibition $(-52.6 \pm 26.6 \% ; n=5)$ was observed with $0.05 \mu \mathrm{M} \mathrm{NVP}-$ AAM077, an antagonist with relative selectivity for NR1/NR2A receptors at low concentrations (Auberson et al., 2002; Liu et al., 2004; Berberich et al., 2005). At concentrations above $0.1 \mu \mathrm{M}$, NVP-AAM077 blocked NMDAR EPSPs completely (Fig. 1A). D,L-APV, a competitive antagonist with less subtype selectivity (Mishina et al., 1993; Buller et al., 1994), inhibited NMDAR EPSPs by $58.0 \pm 7.0 \%$ at $10 \mu \mathrm{M}(n=5)$ (Fig. $1 A, B)$.

To explore the contribution of NMDAR subtypes to the effects of these agents, we examined combinations of NMDAR antagonists. A combination of $10 \mu \mathrm{M}$ ifenprodil and $10 \mu \mathrm{M}$ D,LAPV resulted in nearly complete inhibition of NMDAR EPSPS $(-93.3 \pm 0.7 \% ; n=4)$ (Fig. $1 B)$, suggesting effects on complementary populations of receptors. Because $10 \mu \mathrm{M}$ APV produces greater inhibition than $10 \mu \mathrm{M}$ ifenprodil, their combined effects are not simply additive, suggesting some degree of overlap in their actions. A combination of $10 \mu \mathrm{M}$ zinc and $10 \mu \mathrm{M}$ D,L-APV also resulted in nearly complete block of NMDAR responses (Fig. 1C). Similar effects were observed with $5 \mu \mathrm{M}$ D-APV, the active APV isomer (D-APV data not shown). In the presence of $10 \mu \mathrm{M}$ ifenprodil, however, $10 \mu \mathrm{M}$ zinc produced no additional inhibition of NMDAR EPSPs $(-54.2 \pm 6.0 \%$ for ifenprodil alone vs $-56.5 \pm 6.2 \%$ for ifenprodil plus zinc; $n=4$ ) (Fig. $1 D)$. Similarly, $10 \mu \mathrm{M}$ zinc produced little additional depression of NMDAR EPSPs in the presence of $10 \mu \mathrm{M}$ Ro25-6981 (-49.4 \pm $3.7 \% ; n=5)$, another NR2B antagonist that depressed NMDAR EPSPs by $-38.7 \pm 2.6 \%(n=5)$ when administered alone. In contrast, coadministration of $10 \mu \mathrm{M}$ Ro25-6981 plus $10 \mu \mathrm{M}$ D,LAPV nearly completely suppressed NMDAR EPSPs $(-92.2 \pm$ $0.4 \% ; n=5)$. We also found that administration of $10 \mu \mathrm{M}$ zinc in the presence of $0.05 \mu \mathrm{M}$ NVP-AAM077 led to nearly complete depression of NMDAR EPSPs (Fig. $1 E$ ). These findings suggest that low micromolar concentrations of zinc antagonize a subtype of NR2B-containing synaptic NMDARs and that this subtype overlaps with, but is not identical to, NMDARs blocked by low concentrations of APV or NVP-AAM077.

Because NMDARs are involved in the induction of both LTP and LTD, we examined whether zinc and other NMDAR antagonists alter LTP induced by a single $100 \mathrm{~Hz}, 1 \mathrm{~s}$ HFS and LTD induced by $1 \mathrm{~Hz}, 900$ pulse low-frequency stimulation (LFS). Complete LTP inhibition by D,L-APV was observed at concentrations $\geq 50 \mu \mathrm{M}$. However, $10 \mu \mathrm{M}$ D,L-APV or $5 \mu \mathrm{M}$ D-APV, which depressed individual NMDAR EPSPs by $50-60 \%$ (Fig. 1A,B), had no effect on LTP $[+45.3 \pm 13.4 \%$ change in EPSP slope 60 min after HFS for D,L-APV, $n=5$ (Fig. $2 C$ ); $+56.9 \pm 9.9 \%$ change in D-APV, $n=3$ ]. Similarly, $10 \mu \mathrm{M}$ ifenprodil alone did not alter HFS-induced LTP $(+48.4 \pm 15.5 \% ; n=5)$, although a combination of $10 \mu \mathrm{M}$ ifenprodil and $10 \mu \mathrm{M}$ D,L-APV blocked LTP completely $(n=5)$ (Fig. $2 A)$. Similarly, a combination of 10 $\mu \mathrm{M}$ Ro25-6981 and $10 \mu \mathrm{M}$ D,L-APV blocked LTP completely
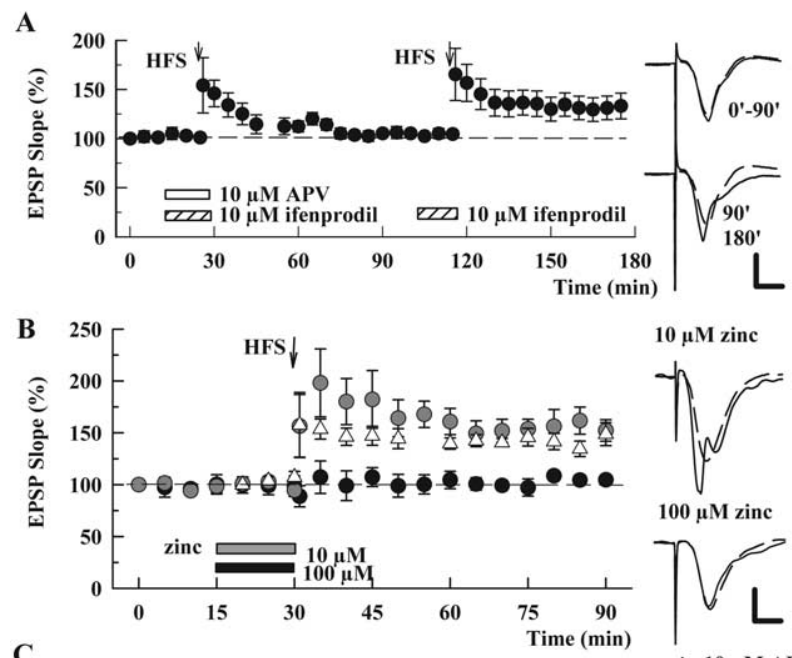

$10 \mu \mathrm{M}$ zinc
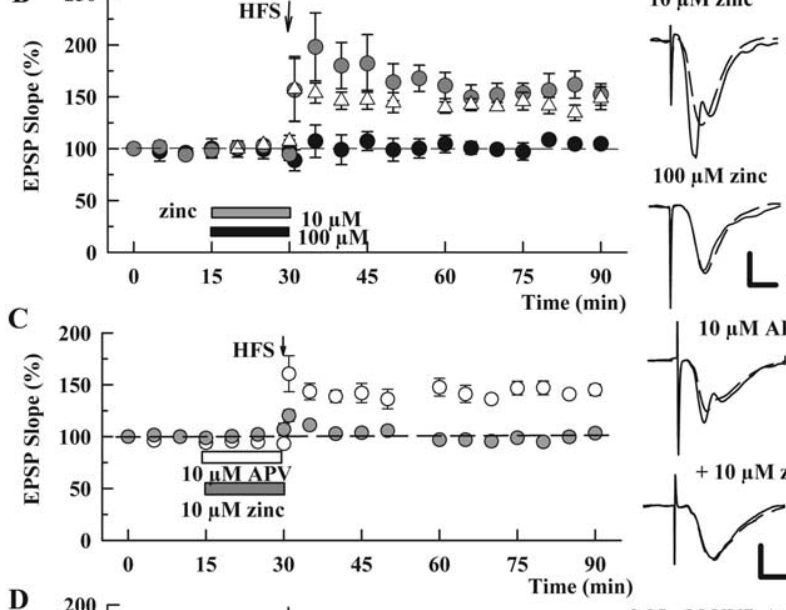

$10 \mu \mathrm{M}$ APV

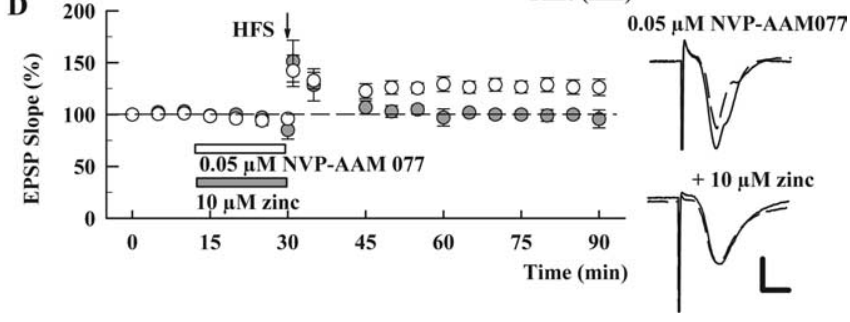

Figure 2. Effects of NMDR antagonists and zinc on LTP. A, HFS ( $100 \mathrm{~Hz}, 1 \mathrm{~s}$; arrow) failed to induce LTP in the presence of both $10 \mu \mathrm{M}$ D,L-APV (white bar) and $10 \mu \mathrm{m}$ ifenprodil (hatched bar) but induced LTP in the presence of ifenprodil alone. $\boldsymbol{B}$, HFS (arrow) induced LTP in control slices (white triangles) and in the presence of $10 \mu \mathrm{m}$ zinc (gray circles) but not in the presence of $100 \mu \mathrm{m}$ zinc (black circles). Zinc was applied for $15 \mathrm{~min}$ before the tetanus (bars). C, HFS induced LTP in the presence of $10 \mu \mathrm{m}$ APV (white circles). The combination of $10 \mu \mathrm{m}$ zinc (gray bar) and $10 \mu \mathrm{m}$ APV (white bar) inhibited LTP induction (gray circles). D, At $0.05 \mu \mathrm{m}$, NVP-AAM077 (white bar) did not completely inhibit LTP (white circles), whereas the combination of NVPAAM077 and $10 \mu \mathrm{m}$ zinc (gray bar) prevented LTP induction (gray circles).

$(-6.1 \pm 4.4 \% ; n=5)$, but Ro25-6981 alone allowed HFSinduced LTP in the same slices $(+28.3 \pm 6.4 \%$; $p<0.01$; Ro256981 data not shown).

Consistent with a previous report (Xie and Smart, 1994), we found that LTP was inhibited by $100 \mu \mathrm{M}$ zinc $(-3.3 \pm 1.7 \%$ change in EPSP slope, $n=3, p<0.05$ vs control) (Fig. $2 B$ ). At 10 $\mu \mathrm{M}$, zinc had no effect on LTP $(+49.3 \pm 9.4 \%$ change in EPSP slope in zinc, $n=4$ vs $+43.6 \pm 6.2 \%$ change in control, $n=5$ ) (Fig. $2 B$ ), although $10 \mu \mathrm{M}$ zinc produced $40-50 \%$ depression of NMDAR EPSPs (Fig. $1 A, C$ ). Although neither $10 \mu \mathrm{M}$ zinc (Fig. $2 B$ ) nor $10 \mu \mathrm{M}$ D,L-APV (Fig. 2C, white circles) alone inhibited LTP, the combination completely blocked LTP induction (Fig. $2 C$, gray circles). At $0.05 \mu \mathrm{M}, \mathrm{NVP}-\mathrm{AAM} 077$ diminished but did not completely eliminate LTP $(+17.2 \pm 2.6 \%$ change in EPSP slope; $n=7$ ) (Fig. $2 D$, white circles). The combination of $0.05 \mu \mathrm{M}$ NVP-AAM077 plus $10 \mu \mathrm{M}$ zinc, like the combination of zinc and APV, completely blocked LTP induction $(-6.9 \pm 3.1 \%$; $n=5)$ (Fig. 2D, gray circles).

In contrast to effects on LTP, $10 \mu \mathrm{M}$ ifenprodil inhibited LTD $(-9.5 \pm 7.2 \%$ change; $n=6 ; p<0.01$ compared with control 
$\mathbf{A}$
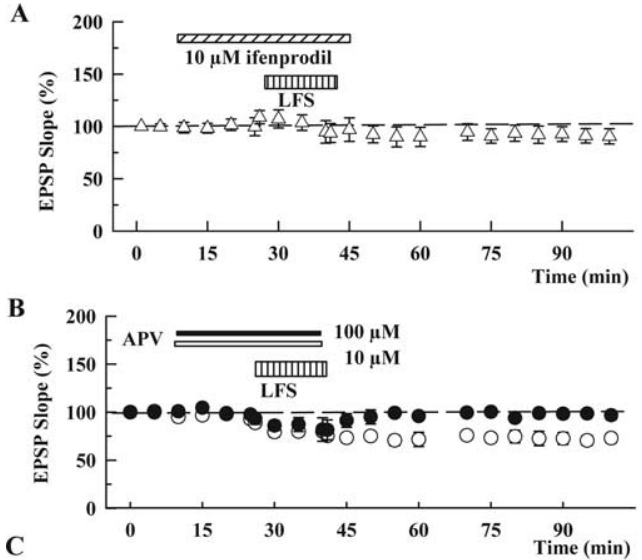

C
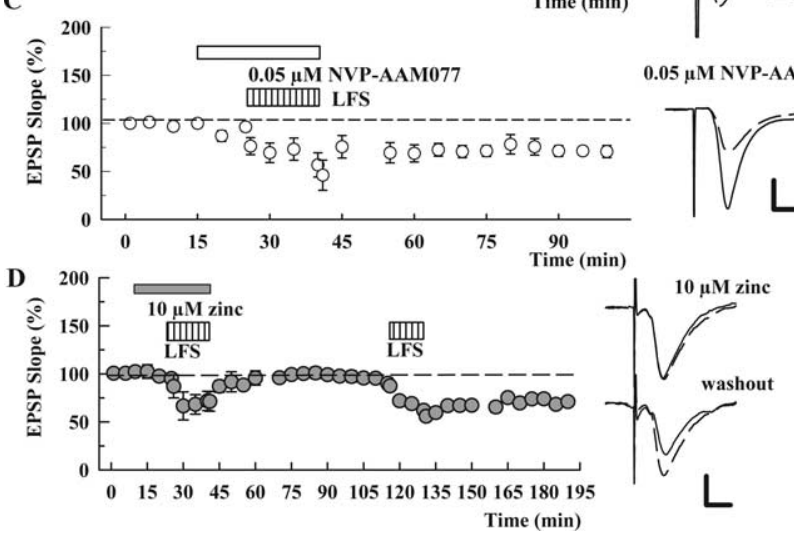

Figure 3. Effects of NMDAR antagonists and zinc on LTD. $A$, LFS $(1 \mathrm{~Hz}, 900 \mathrm{~s}$, vertical striped bar) failed to induce LTD in the presence of $10 \mu \mathrm{m}$ ifenprodil (hatched bar). $\boldsymbol{B}$, LFS induced LTD in the presence of $10 \mu \mathrm{m}$ (white circles) but not $100 \mu \mathrm{m}$ D,L-APV (black circles). C, LFS induced LTD in the presence of $0.05 \mu \mathrm{m}$ NVP-AAM077. D, LFS failed to induce LTD in the presence of 10 $\mu \mathrm{m}$ zinc (gray bar) but after zinc washout LTD was induced. Traces on the right are field EPSPS obtained before (dashed traces) and 60 min after (solid traces) LFS. Calibration: 1 mV, 5 ms.

LTD) (Fig. 3A), suggesting an important role for NR1/NR2B receptors in LTD induction. Similar effects on LTD were observed with $10 \mu \mathrm{M}$ Ro25-6981 ( $-0.6 \pm 1.2 \%$ change; $n=4)$. LFS-induced LTD was also inhibited by $100 \mu \mathrm{M}$ D,L-APV $(-5.2 \pm$ $5.1 \%$ change; $n=5$ ) (Fig. $3 B$ ) or $50 \mu \mathrm{M}$ D-APV $(-2.2 \pm 1.3 \%$ change; $n=4$ ) but not by $10 \mu \mathrm{M}$ D,L-APV or $5 \mu \mathrm{M}$ D-APV. At 0.05 $\mu \mathrm{M}$, NVP-AAM077 also had no effect on LTD induction $(-30.5 \pm 4.7 \%$ change; $n=5)$ (Fig. $3 C$ ).

Although $10 \mu \mathrm{M}$ zinc did not alter LTP (Fig. 2 B), 1 and $10 \mu \mathrm{M}$ zinc significantly diminished LTD $(0.1 \mu \mathrm{M}$ zinc, $-25.5 \pm 4.0 \%$ change in EPSP slope $60 \mathrm{~min}$ after $1 \mathrm{~Hz}$ LFS, $n=4 ; 1 \mu \mathrm{M}$ zinc, $-11.0 \pm 5.7 \%$ change, $n=5 ; 10 \mu \mathrm{M}$ zinc, $-0.9 \pm 3.6 \%$ change, $n=8 ; p<0.05$ for 1 and $10 \mu \mathrm{M}$ zinc vs control, $-33.7 \pm 5.4 \%$ change, $n=5$ ) (Fig. 3D). The effects of $10 \mu \mathrm{M}$ zinc were reversible, and a second LFS administered 75 min after zinc washout produced robust LTD $(-29.1 \pm 4.5 \%$ change; $n=4)($ Fig. $3 D)$. LTD inhibition by $10 \mu \mathrm{M}$ zinc was not altered in slices treated with $100 \mu \mathrm{M}$ picrotoxin $(+0.4 \pm 5.1 \%$ change; $n=3)$, indicating that effects of zinc on $\mathrm{GABA}_{\mathrm{A}}$ receptors do not contribute to LTD inhibition.

These first sets of experiments suggest that low micromolar concentrations of zinc inhibit a specific population of synaptic NMDARs. If zinc-mediated inhibition of LTD and LTP results solely from actions at NMDARs, then LTD involves NMDARs with higher apparent affinity for zinc than the receptors involved in LTP. Given the concentrations of zinc required to inhibit LTP and LTD and the effects of ifenprodil, these studies further sug-
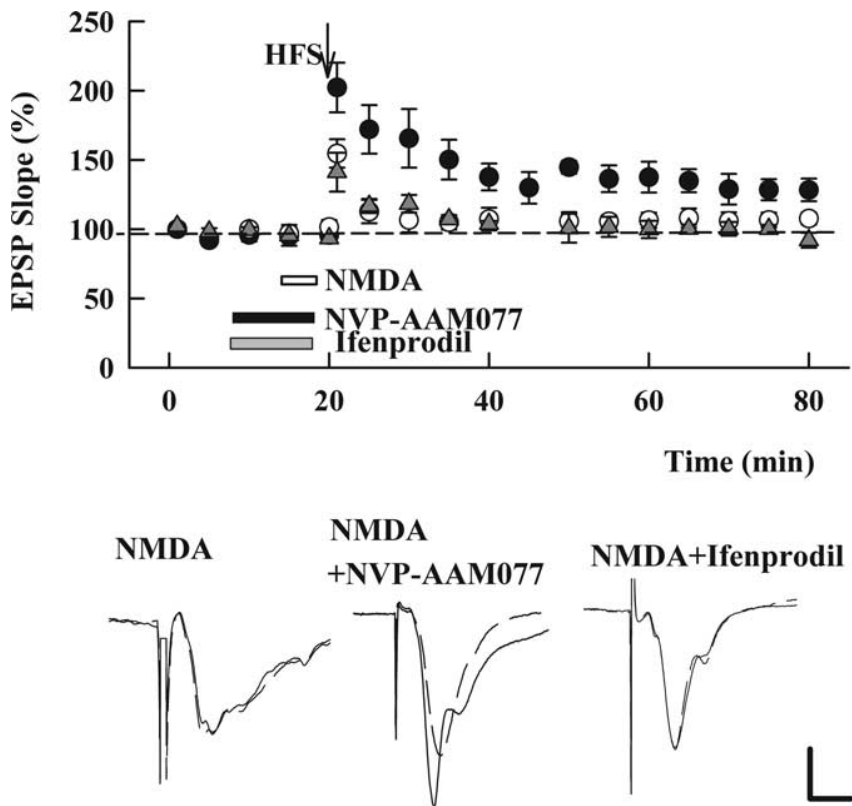

Figure 4. NVP-AAM077 prevents NMDA-mediated LTP inhibition. As reported previously (Izumi et al., 1992), a $100 \mathrm{~Hz}, 1$ s HFS (arrow) delivered in the presence of $1 \mu \mathrm{m} \mathrm{NMDA} \mathrm{(white}$ bar) inhibits LTP induction (white circles; $n=7$ ). Administration of $0.05 \mu \mathrm{m}$ NVP-AAM077 (black bar) with NMDA allowed LTP (black circles; $n=4$ ), whereas $10 \mu \mathrm{m}$ ifenprodil (gray triangles; $n=3$ ) was ineffective. Drugs were administered for the duration noted by the bars, and the tetanus (HFS) was delivered at the time denoted by the arrow. These results indicate that LTP inhibition mediated by untimely activation of NMDA receptors results from activation of NR1/NR2A receptors. We reported previously that $10 \mu \mathrm{M}$ D,L-APV overcomes the LTP inhibition by $1 \mu$ M NMDA (Izumi et al., 1992a,b). Traces depict EPSPs before and 60 min after HFS. Calibration: $1 \mathrm{mV}, 5 \mathrm{~ms}$.

gest that zinc-induced LTP inhibition requires effects on lower affinity NR1/NR2A sites, whereas LTD inhibition results from effects on NR1/NR2B receptors (Chen et al., 1997; Paoletti et al., 1997; Rachline et al., 2005). These findings, however, do not address the role of the high-affinity zinc block of NR1/NR2A receptors. The following studies were designed to examine the potential role of high-affinity zinc block in synaptic function.

Previous studies have shown that untimely NMDAR activation by brief exposure to low concentrations of NMDAR agonists (Izumi et al., 1992a,b; Kato et al., 1999) or low magnesium (Coan et al., 1989) blocks CA1 LTP induction and that this LTP inhibition is overcome by low micromolar concentrations of APV. We found that $0.05 \mu \mathrm{M}$ NVP-AAM077 also overcame the inhibitory effects of $1 \mu \mathrm{M}$ NMDA on LTP $(+23.1 \pm 2.1 \%$ change 60 min after the tetanus; $n=4$ ) (Fig. 4), but $10 \mu \mathrm{M}$ ifenprodil was ineffective $(-4.4 \pm 2.2 \%$ change; $n=3$ ) (Fig. 4$)$. These results suggest that NR2A-containing but not NR2B-containing receptors contribute to this form of metaplasticity.

Because high-affinity zinc sites on NR2A are likely to be substantially occupied under physiological conditions (Frederickson, 1989; Erreger and Traynelis, 2005; Frederickson et al., 2006), this raises the possibility that ambient zinc may modulate LTP by preventing untimely NR1/NR2A activation. To test this, we examined the effects of zinc chelators. Although $2 \mathrm{~mm} \mathrm{Ca-EDTA}$, an effective extracellular zinc chelator (Koh et al., 1996), did not alter isolated NMDAR EPSPs $(-4.2 \pm 4.4 \%$ change; $n=8$ ) (Fig. $5 A$ ), it blocked HFS-induced LTP (Fig. $5 B$ ). The effects of CaEDTA did not require synaptic activation during the period of EDTA exposure because administering the chelator without synaptic stimulation and removing the chelator before tetanization 


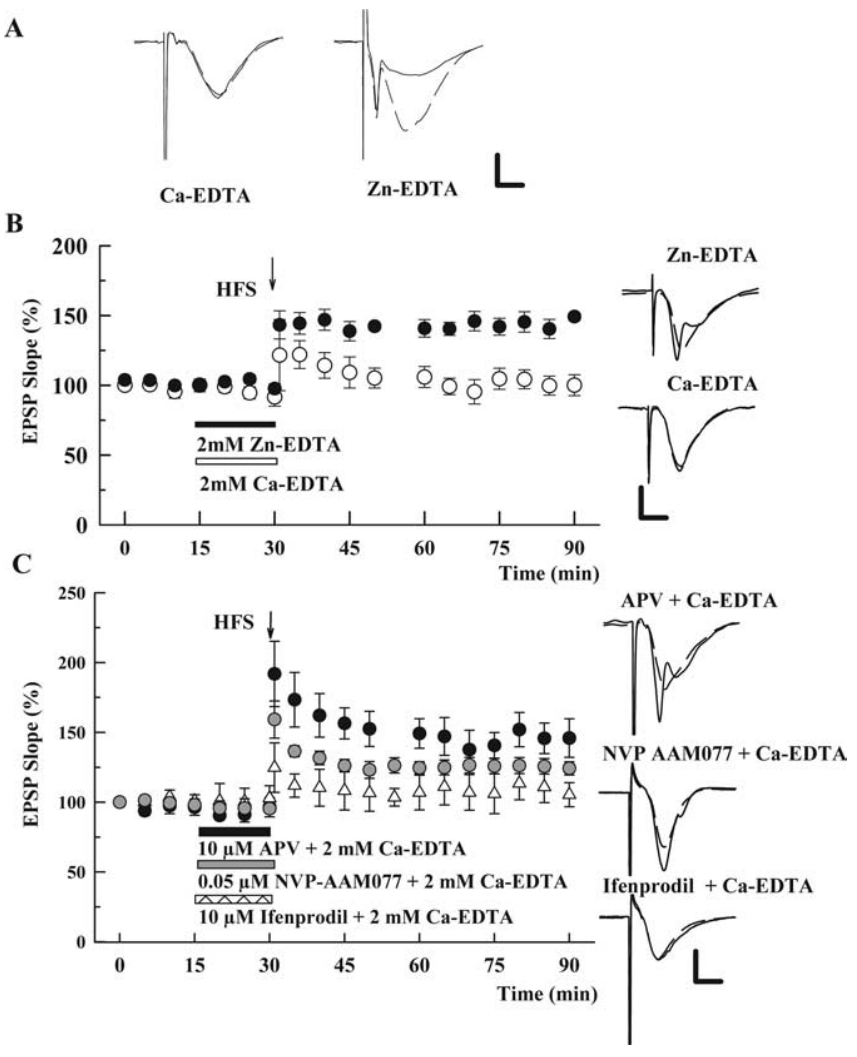

Figure 5. Effects of NMDAR antagonists on EDTA-mediated LTP inhibition. A, Administration of $2 \mathrm{~mm}$ Ca-EDTA for $15 \mathrm{~min}$ does not alter NMDAR EPSPs $(104.0 \pm 4.6 \%$ of control; $n=4)$. In contrast, administration of $2 \mathrm{~mm}$ Zn-EDTA for 15 min partially inhibited NMDAR EPSPs (34.3 \pm $14.9 \%$ of control; $n=5$ ). $\boldsymbol{B}$, The graph shows the effects of 15 min perfusion of $2 \mathrm{~mm}$ Ca-EDTA (white circles) or $2 \mathrm{~mm}$ Zn-EDTA (black circles) on LTP induction. HFS (arrow) was delivered in the presence of EDTA (bars). The results indicate that a Ca-EDTA chelatable, but not Zn-EDTA chelatable, agent inhibits LTP induction. C, The graph shows the effects of $10 \mu \mathrm{m}$ D,L-APV (black circles), $0.05 \mu \mathrm{M}$ NVP-AAM 077 (gray circles), and $10 \mu \mathrm{m}$ ifenprodil (white triangles) on CaEDTA-mediated LTP inhibition. Whereas APV and NVP-AAM077 allowed LTP induction, ifenprodil failed to promote LTP in the presence of Ca-EDTA, suggesting that LTP inhibition by zinc chelation results from activation of NMDARs expressing NR1/NR2A but not NR1/NR2B. Traces to the right show representative EPSPs before (dashed traces) and $60 \mathrm{~min}$ after (solid traces) the tetanus. Calibration: $1 \mathrm{mV}, 5 \mathrm{~ms}$.

still blocked LTP $(-5.7 \pm 2.6 \%$ change; $n=4)$. Zn-EDTA, a chelator that is inefficient in binding extracellular zinc because it is already complexed with the ion (Koh et al., 1996), had no effect on LTP (Fig. 5B), although it partially depressed NMDAR EPSPs (Fig. 5A). The partial depression of NMDA EPSPs by $2 \mathrm{~mm} \mathrm{Zn-}$ EDTA likely reflects the presence of a low micromolar concentration of free zinc during perfusion of the chelator. The results with Zn-EDTA, including effects on NMDAR EPSPs, support the idea that the block of LTP by Ca-EDTA does not result from inhibitory effects of EDTA on synaptic NMDARs. In contrast to effects on LTP, Ca-EDTA had no effect on LTD induction $(-46.4 \pm$ $16.1 \%$ change in EPSP slope; $n=4$ ).

The LTP block by Ca-EDTA was overcome by coadministration of $10 \mu \mathrm{M}$ D,L-APV $(+40.7 \pm 7.8 \%$ change in EPSP slope; $n=$ 5) (Fig. 5C), suggesting that zinc chelation promotes a form of NMDAR-mediated LTP inhibition. Consistent with our findings with $1 \mu \mathrm{M}$ NMDA (Fig. 4), we found that $0.05 \mu \mathrm{M}$ NVP-AAM077 also overcame the LTP inhibition by Ca-EDTA $(+20.1 \pm 2.5 \%$ change in EPSP slope; $n=5$ ) (Fig. 5C). Although NVP-AAM077 diminishes LTP relative to controls, the degree of LTP with NVPAAM077 was the same in the presence or absence of Ca-EDTA
A
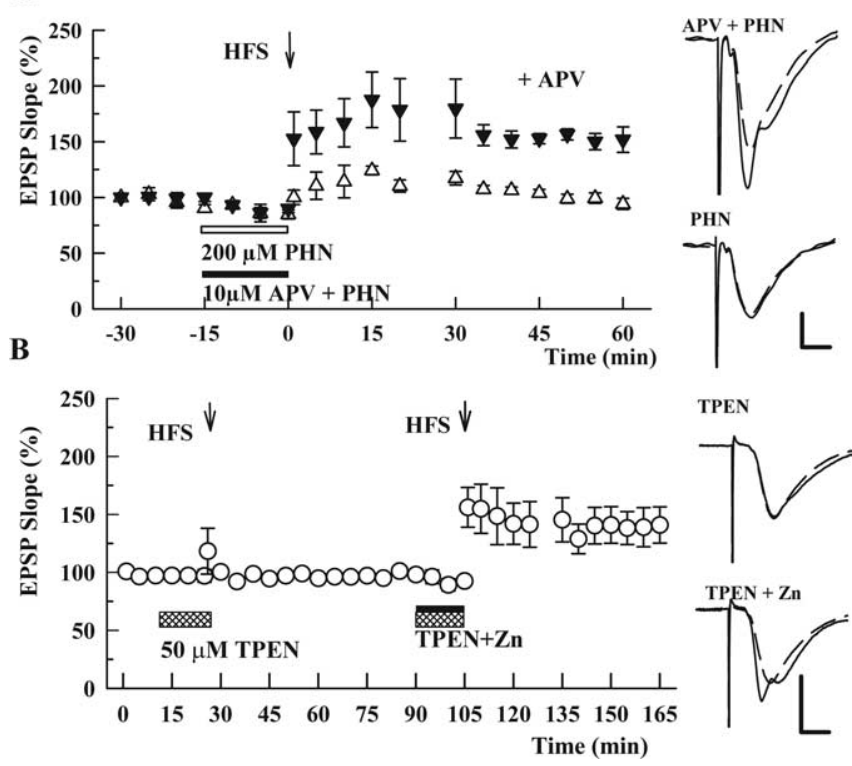

TPEN

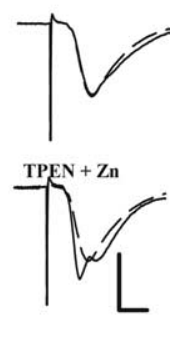

Figure 6. Other zinc chelators inhibit LTP. A, PHN, a zinc chelator, mimics the effects of $2 \mathrm{~mm}$ Ca-EDTA. HFS failed to induce LTP in the presence of $200 \mu \mathrm{m}$ PHN (white bar, white triangles). Coadministration of $10 \mu \mathrm{M}$ APV (black bar) with PHN allowed LTP induction $(n=5$; black triangles). $\boldsymbol{B}$, Similarly, in the presence of $50 \mu \mathrm{m}$ TPEN, a third zinc chelator, LFS failed to induce LTP. TPEN administered with $10 \mu \mathrm{m}$ zinc (black bar) allowed LTP induction. Traces depict EPSPS before and $60 \mathrm{~min}$ after HFS. Calibration: $1 \mathrm{mV}, 5 \mathrm{~ms}$.

(Fig. 2D). In contrast, $10 \mu \mathrm{M}$ ifenprodil did not alter LTP inhibition by Ca-EDTA $(-3.6 \pm 5.8 \%$ change; $n=5)$ (Fig. $5 C$ ).

We also examined two other zinc chelators and found similar effects. LTP was blocked $200 \mu \mathrm{M} o$-phenanthroline (PHN) $(-7.4 \pm 7.0 \%$ change; $n=4 ; p<0.05$ vs control), and this LTP inhibition was reversed by $10 \mu \mathrm{M}$ D,L-APV $(+48.7 \pm 6.5 \%$ change; $n=4 ; p<0.05$ compared with PHN alone) (Fig. 6A). Similarly, LTP induction was blocked by $50 \mu \mathrm{M} N, N, N^{\prime}, N^{\prime}$, tetrakis (2-pyridylmethyl) ethylenediaminepentaethylene (TPEN), a potent zinc chelator $(-2.9 \pm 0.6 \% ; n=5$ ) (Fig. $6 B$ ) (Paoletti et al., 1997). In the same slices, administration of $10 \mu \mathrm{M}$ zinc with TPEN enabled LTP induction $(+40.9 \pm 15.6 \%$ change; $n=5)$ (Fig. $6 B$ ). Even at $50 \mu \mathrm{M}$ zinc, we found partial reversal of LTP inhibition in the presence of TPEN $(+23.7 \pm 5.2 \% ; n=3)$. We also found that $30 \mu \mathrm{M}$ exogenous zinc coadministered with $2 \mathrm{mM}$ Ca-EDTA overcame the inhibitory effect of EDTA on LTP induction $(+38.0 \pm 11.0 \%$ change; $n=5)$ but that $10 \mu \mathrm{M}$ zinc plus EDTA did not fully restore LTP $(+16.0 \pm 14.7 \% ; n=3)$.

The conclusion that NMDARs contribute to the block of LTP by zinc chelators requires that these chelators effectively buffer extracellular zinc. We tested this by examining the effects of exogenous zinc on NMDAR EPSPs in the absence and presence of Ca-EDTA. Although $10 \mu \mathrm{M}$ zinc inhibited NMDAR EPSPs by $40-50 \%$ in control slices (Fig. $1 A, C$ ), $10 \mu \mathrm{M}$ zinc had no effect during coadministration of $2 \mathrm{mM}$ Ca-EDTA $(-4.2 \pm 0.8 \%$ change; $n=4)$.

\section{Discussion}

The present study indicates that NR1/NR2A and NR1/NR2B NMDARs play complex roles in CA1 synaptic plasticity and that zinc, acting via these receptors, can modulate bidirectional plasticity. Native NMDARs are formed by several distinct subunits. NR1 subunits are widely distributed throughout the brain (Moriyoshi et al., 1991), whereas NR2 subunits show differences in regional expression. Functional native NMDARs are hetero- 
multimers of NR1 and NR2 subunits (Kutsuwada et al., 1992; Meguro et al., 1992; Monyer et al.; 1992; Ishii et al., 1993), and the specific NR2 subunits that are expressed with NR1 help to determine the diversity of physiological and pharmacological properties of native receptors (Cull-Candy and Leszkiewicz, 2004). In the hippocampus, two NMDAR subclasses (NR1/NR2A and NR1/NR2B) are thought to be preferentially expressed based on in situ hybridization and immunochemistry (Ishii et al., 1993; Monyer et al., 1994; Wenzel et al., 1995). There is also evidence that triheteromeric receptors expressing NR1, NR2A, and NR2B exist in the CNS and may be expressed at mature synapses (Luo et al., 1997; Kew et al., 1998; Tovar and Westbrook, 1999).

Experiments using mice with selective deletions of different NMDAR subunits are consistent with the results presented here, although interpretation of experiments using mice with targeted deletions of NMDAR subunits is difficult because NR1 ( $\zeta 1$ in mouse) and NR2B ( $\varepsilon 2$ in mouse) mutants die early in life (Forrest et al., 1994; Kutsuwada et al., 1996; Sprengel et al., 1998). However, experiments performed early in the postnatal period when mice with NR2B deletions are still viable indicate that the absence of NR2B subunits greatly impairs the induction LTD in the CA1 region (Kutsuwada et al., 1996). These observations are consistent with results showing an important role of ifenprodilsensitive NMDARs in LTD initiation (Liu et al., 2004; Massey et al., 2004). Other studies indicate that mice with deletions of the NR2A ( $\varepsilon 1$ in mouse) gene exhibit diminished LTP at CA1 hippocampal synapses (Sakimura et al., 1995).

Ifenprodil and Ro25-6981 are relatively selective antagonists of NMDARs containing NR2B (Williams, 1993; Priestley et al., 1995; Hatton and Paoletti, 2005), and there is evidence that the ifenprodil and zinc sites on NR2B overlap (Rachline et al., 2005). In contrast, NVP-AAM077 is an antagonist with relative selectivity for NR1/NR2A receptors (Auberson et al., 2002; Liu et al., 2004; Massey et al., 2004), although the concentration range for selectivity is more restricted than initially reported (Berberich et al., 2005; Weitlauf et al., 2005; Neyton and Paoletti, 2006). We found that NVP-AAM077 has some selectivity for NR2A at concentrations $<0.1 \mu \mathrm{M}$, and, at $0.05 \mu \mathrm{M}$, NVP-AAM077 does not occlude the effects of $10 \mu \mathrm{M}$ zinc. Similarly, $10 \mu \mathrm{M}$ D,L-APV inhibited NMDAR EPSPs by $50-60 \%$, and the combination of APV and ifenprodil or Ro25-6981 produced complementary inhibition of NMDAR EPSPs. Studies using recombinant NMDARs indicate that APV has approximately threefold greater potency at NR1/NR2A receptors compared with NR1/NR2B (Mishina et al., 1993; Buller et al., 1994; Grimwood et al., 1996; Liu et al., 2004).

Using a series of competitive antagonists with varied affinities for NMDAR subtypes, Hrabetova et al. (2000) found that distinct NMDAR subtypes were involved in the induction of CA1 LTP and LTD. Antagonists with higher affinity for NR2A or NR2B receptors were more potent inhibitors of LTP and LTD compared with antagonists with higher NR2C or NR2D affinity. Recent studies indicate that NR1/NR2B-selective antagonists preferentially inhibit LTD, whereas NR1/NR2A antagonists preferentially disrupt LTP (Liu et al., 2004; Massey et al., 2004) (but see Hendricson et al., 2002). Other studies suggest, however, that activation of either NMDAR subtype can result in LTP (Berberich et al., 2005; Weitlauf et al., 2005). Consistent with the latter findings, we found that LTP was not completely blocked by inhibition of only one NMDAR subtype. In contrast, LTD was inhibited by specific block of the NR1/NR2B subclass. Despite similar degrees of NMDAR EPSP inhibition by $10 \mu \mathrm{M}$ D,L-APV, $0.05 \mu \mathrm{M}$ NVP-
AAM077, $10 \mu \mathrm{M}$ ifenprodil, and $10 \mu \mathrm{M}$ Ro25-6981, only ifenprodil and Ro25-6981 blocked LTD induction.

Zinc has multiple effects on NMDARs. NR1/NR2B receptors are inhibited by low micromolar concentrations of zinc with halfmaximal inhibition at $\sim 0.5-5 \mu \mathrm{M}$, whereas receptors containing NR1/NR2A require $\sim 100 \mu \mathrm{M}$ zinc for nearly complete inhibition (Grimwood et al., 1996; Williams, 1996; Paoletti et al., 1997). In addition to the high sensitivity of NR1/NR2B receptors, NR1/ NR2A receptors have two distinct sites for zinc: one that is exquisitely sensitive $\left(\mathrm{IC}_{50}\right.$ of $\sim 0.005-0.08 \mu \mathrm{M}$ ) and the other that has substantially lower apparent affinity $\left(\mathrm{IC}_{50}\right.$ of $\left.\sim 26-79 \mu \mathrm{M}\right)$ (Williams, 1996; Chen et al., 1997; Paoletti et al., 1997). Triheteromeric receptors expressing NR1/NR2A/NR2B retain high zinc sensitivity but are less effectively inhibited compared with diheteromers (Hatton and Paoletti, 2005).

Our observations suggest that the component of NMDAR EPSPs that is sensitive to low micromolar zinc likely reflects NR1/ NR2B and/or the high-affinity site on NR1/NR2A. Because the concentration of free zinc in brain extracellular fluid of anesthetized rats is $\sim 0.02 \mu \mathrm{M}$ (Frederickson et al., 2006) and 0.15-0.30 $\mu \mathrm{M}$ in CSF (Frederickson, 1989), it seems likely that high-affinity NR1/NR2A zinc sites are significantly occupied under ambient physiological conditions (Erreger and Traynelis, 2005). Indeed, some studies indicate that extracellular zinc chelators modulate basal function of NMDARs in the CA3 region (Vogt et al., 2000). Consistent with this, we found that zinc chelation results in a form of NMDAR-mediated LTP inhibition in CA1 that likely involves tonic NR1/NR2A receptor activation by ambient glutamate (Sah et al., 1989; Zorumski et al., 1996).

The presence of zinc in synaptic terminals and its extracellular release during synaptic transmission (Assaf and Chung, 1984; Howell et al., 1984) raise the possibility that zinc is an important modulator of plasticity in the hippocampus. Our studies with zinc chelators suggest that basal zinc concentrations play a role in fostering CA1 LTP induction by preventing the LTP inhibition that occurs with untimely NMDAR activation. This LTP inhibition preferentially involves NR1/NR2A receptors because NR2A antagonists, but not ifenprodil, overcome the effect. Interestingly, we found no effect of zinc chelators on NMDAR EPSPs, suggesting that the effects of ambient zinc may primarily involve extrasynaptic NR1/NR2A receptors (Thomas et al., 2006). Although it is unknown whether synaptic and extrasynaptic NR2A receptors differ in zinc sensitivity, postsynaptic density-95, a protein highly expressed at CA1 excitatory synapses, diminishes high-affinity NR1/NR2A zinc inhibition (Yamada et al., 2002). The lack of effect of zinc chelators on NMDAR EPSPs is also consistent with previous studies in which we found that low micromolar concentrations of NMDA block LTP but have no effect on NMDAR EPSPs (Izumi et al., 1992a,b). In contrast, effects on LTD require increases in zinc concentration into the low micromolar range as might occur during periods of increased synaptic activity or altered zinc transport (Smart et al., 2004).

In summary, we find that zinc modulates CA1 synaptic plasticity by at least three mechanisms. Block of NR1/NR2B receptors by low micromolar zinc inhibits LTD. High micromolar zinc blocks LTP, likely via a combination of effects on the two NR1/ NR2A sites plus the NR1/NR2B site. At the nanomolar concentrations present in brain extracellular fluid, zinc appears to promote LTP by inhibiting a form of metaplasticity resulting from untimely NR1/NR2A activation. These results suggest that regulation of extracellular zinc can have important effects on CA1 hippocampal function. 


\section{References}

Assaf SY, Chung SH (1984) Release of endogenous $\mathrm{Zn}^{2+}$ from brain tissue during activity. Nature 308:734-736.

Auberson YP, Allgeier H, Bischoff S, Lingenhoehl K, Moretti R, Schmutz M (2002) 5-Phosphonomethylquinoxalinediones as competitive NMDA receptor antagonists with a preference for the human $1 \mathrm{~A} / 2 \mathrm{~A}$, rather than 1A/2B receptor composition. Bioorg Med Chem Lett 12:1099-1102.

Berberich S, Punnakkal P, Jensen M, Pawlak V, Seeburg PH, Hvalby O, Kohr G (2005) Lack of NMDA receptor subtype selectivity for hippocampal long-term potentiation. J Neurosci 25:6907-6910.

Buller AL, Larson HC, Schneider BE, Beaton JA, Morrisett RA, Monaghan DT (1994) The molecular basis of NMDA receptor subtypes: native receptor diversity is predicted by subunit composition. J Neurosci 14:5471-5484.

Chen N, Moshaver A, Raymond LA (1997) Differential sensitivity of recombinant $N$-methyl-D-aspartate receptor subtypes to zinc inhibition. Mol Pharmacol 51:1015-1023.

Choi YB, Lipton SA (1999) Identification and mechanism of action of two histidine residues underlying high-affinity $\mathrm{Zn}^{2+}$ inhibition of the NMDA receptor. Neuron 23:171-180.

Coan EJ, Irving AJ, Collingridge GL (1989) Low frequency activation of the NMDA receptor system can prevent the induction of LTP. Neurosci Lett 105:205-210.

Cull-Candy SG, Leszkiewicz DN (2004) Role of distinct NMDA receptor subtypes at central synapses. Sci STKE 2004:re16.

Erreger K, Traynelis SF (2005) Allosteric interaction between zinc and glutamate binding domains on NR2A causes desensitization of NMDA receptors. J Physiol (Lond) 569:381-393.

Forrest D, Yuzaki M, Soares HD, Ng L, Luk DC, Sheng M, Steward CL, Morgan JI, Connor JA, Curran T (1994) Targeted disruption of NMDA receptor 1 gene abolishes NMDA response and results in neonatal death. Neuron 12:325-338.

Frederickson CJ (1989) Neurobiology of zinc and zinc-containing neurons. Int Rev Neurobiol 31:145-238.

Frederickson CJ, Giblin LJ, Krezel A, McAdoo DJ, Muelle RN, Zeng Y, Balaji RV, Masalha R, Thompson RB, Fierke CA, Sarvey JM, de Valdenebro M, Prough DS, Zornow MH (2006) Concentrations of extracellular free zinc $(\mathrm{pZn})_{\mathrm{e}}$ in the central nervous system during simple anesthetization, ischemia and reperfusion. Exp Neurol 198:285-293.

Grimwood S, Gilbert E, Ragan CI, Hutson PH (1996) Modulation of $45 \mathrm{Ca}^{2+}$ influx into cells stably expressing recombinant human NMDA receptors by ligands acting at distinct recognition sites. J Neurochem 66:2589-2595.

Harris EW, Cotman CW (1986) Long-term potentiation of guinea pig mossy fiber responses is not blocked by $\mathrm{N}$-methyl-D-aspartate antagonists. Neurosci Lett 70:132-137.

Hatton CJ, Paoletti P (2005) Modulation of triheteromeric NMDA receptors by N-terminal domain ligands. Neuron 46:261-274.

Hendricson AW, Miao CL, Lippmann MJ, Morrisett RA (2002) Ifenprodil and ethanol enhance NMDA receptor-dependent long-term depression. J Pharmacol Exp Ther 301:938-944.

Howell GA, Welch MG, Frederickson CJ (1984) Stimulation-induced uptake and release of zinc in hippocampal slices. Nature 308:736-738.

Hrabetova S, Serrano P, Blace N, Tse HW, Skifter DA, Jane DE, Monaghan DT, Sacktor TC (2000) Distinct NMDA receptor subpopulations contribute to long-term potentiation and long-term depression induction. J Neurosci 20:RC81(1-6).

Ishii T, Moriyoshi K, Sugihara H, Sakurada K, Kadotani H, Yokoi M, Akazawa C, Shigemoto R, Mizuno N, Masu M, Nakanishi S (1993) Molecular characterization of the family of the $\mathrm{N}$-methyl-D-aspartate receptor subunits. J Biol Chem 268:2836-2843.

Izumi Y, Clifford DB, Zorumski CF (1992a) Low concentrations of $\mathrm{N}$-methyl-D-aspartate inhibit the induction of long-term potentiation in rat hippocampal slices. Neurosci Lett 137:245-248.

Izumi Y, Clifford DB, Zorumski CF (1992b) Inhibition of long-term potentiation by NMDA-mediated nitric oxide release. Science 257:1273-1276.

Kato K, Li SY, Zorumski CF (1999) Modulation of long-term potentiation induction in the hippocampus by $\mathrm{N}$-methyl-D-aspartate-mediated presynaptic inhibition. Neuroscience 92:1261-1272.

Kew JNC, Richards JG, Mutel V, Kemp JA (1998) Developmental changes in NMDA receptor glycine affinity and ifenprodil sensitivity reveal three distinct populations of NMDA receptors in individual rat cortical neurons. J Neurosci 18:1935-1943.

Koh JY, Suh SW, Gwag BJ, He Y, Hsu CY, Choi DW (1996) The role of zinc in selective neuronal death after transient global cerebral ischemia. Science 272:1013-1016.

Kutsuwada T, Kashiwabuchi N, Mori H, Sakimura K, Kushiya E, Araki K, Meguro H, Masaki H, Kumanishi T, Arakawa M, Mishina M (1992) Molecular diversity of the NMDA receptor channel. Nature 358:36-41.

Kutsuwada T, Sakimura K, Manabe T, Takayama C, Katakura N, Kushiiya E, Natsume R, Watantabe M, Inoue Y, Yagi T, Aizawa S, Arakawa M, Takahashi T, Nakamura Y, Mori H, Mishina M (1996) Impairment of suckling response, trigeminal neuronal pattern formation, and hippocampal LTD in NMDA receptor 2 subunit mutant mice. Neuron 16:333-344.

Liu L, Wong TP, Pozza MF, Lingenhoehl K, Wang Y, Sheng M, Auberson YP, Wang YT (2004) Role of NMDA receptor subtypes in governing the direction of hippocampal synaptic plasticity. Science 304:1021-1024.

Luo J, Wang Y, Yasuda RP, Dunah AW, Wolfe BB (1997) The majority of $\mathrm{N}$-methyl-D-aspartate receptor complexes in adult rat cerebral cortex contain at least three different subunits (NR1/NR2A/NR2B). Mol Pharmacol 51:79-86.

Malenka RC, Bear MF (2004) LTP and LTD: an embarrassment of riches. Neuron 44:5-21.

Massey PV, Johnson BE, Moult PR, Auberson YP, Brown MW, Molnar E, Collingridge GL, Bashir ZI (2004) Differential roles of NR2A and NR2B-containing NMDA receptors in cortical long-term potentiation and long-term depression. J Neurosci 24:7821-7828.

Mayer ML, Armstrong N (2004) Structure and function of glutamate receptor ion channels. Annu Rev Physiol 66:161-181.

Meguro H, Mori H, Araki K, Kushiya E, Kutsuwada T, Yamazaki M, Kumanishi T, Arakawa T, Sakimura K, Mishina M (1992) Functional characterization of a heteromeric NMDA receptor channel expressed from cloned cDNAs. Nature 357:70-74.

Mishina M, Mori H, Araki K, Kushiya E, Meguro H, Kutsuwada T, Kashiwabuchi N, Ikeda K, Nagasawa M, Yamazaki M, Masaki H, Yamakura T, Morita T, Sakimura K (1993) Molecular and functional diversity of the NMDA receptor channel. Ann NY Acad Sci 707:136-152.

Monyer H, Sprengel R, Schoepfer R, Herb A, Higuchi M, Lomeli H, Burnashev N, Sakmann B, Seeburg PH (1992) Heteromeric NMDA receptors: molecular and functional distinction of subtypes. Science 256:1217-1221.

Monyer H, Burnashev N, Laurie DJ, Sakmann B, Seeburg PH (1994) Developmental and regional expression in the rat brain and functional properties of four NMDA receptors. Neuron 12:529-540.

Moriyoshi K, Masu M, Ishii T, Shigemoto R, Mizuno N, Nakanishi S (1991) Molecular cloning and characterization of the rat NMDA receptor. Nature 354:31-37.

Neyton J, Paoletti P (2006) Relating NMDA receptor function to receptor subunit composition: limitations of the pharmacological approach. J Neurosci 26:1331-1333.

Paoletti P, Ascher P, Neyton J (1997) High-affinity zinc inhibition of NMDA NR1-NR2A receptors. J Neurosci 17:5711-5725.

Priestley T, Laughton P, Myers J, Le Bourdelles B, Kerby J, Whiting PJ (1995) Pharmacological properties of recombinant human $N$-methyl-Daspartate receptors comprising NR1a/NR2A and NR1a/NR2B subunit assemblies expressed in permanently transfected mouse fibroblast cells. Mol Pharmacol 48:841-848.

Rachline J, Perin-Dureau F, Le Goff A, Neyton J, Paoletti P (2005) The micromolar zinc-binding domain on the NMDA receptor subunit NR2B. J Neurosci 25:308-317.

Sah P, Hestrin S, Nicoll RA (1989) Tonic activation of NMDA receptors by ambient glutamate enhances excitability of neurons. Science 246:815-818.

Sakimura K, Kutsuwada T, Ito I, Manabe T, Takayama C, Kushiya E, Yagi T, Aizawa S, Inoue Y, Sugiyama H, Mishina M (1995) Reduced hippocampal LTP and spatial learning in mice lacking NMDA receptor $\varepsilon 1$ subunit. Nature 373:151-155.

Smart TG, Hosie AM, Miller PS (2004) $\mathrm{Zn}^{2+}$ ions: modulators of excitatory and inhibitory synaptic activity. The Neuroscientist 10:432-442.

Sprengel R, Suchanek B, Amico C, Brusa R, Burnashev N, Rozov A, Hvalby O, Jensen V, Paulsen O, Andersen P, Kim JJ, Thompson RF, Sun W, Webster LC, Grant SGN, Eilers J, Konnerth A, Li J, McNamara JO, Seeburg PH 
(1998) Importance of the intracellular domain of NR2 subunits for NMDA receptor function in vivo. Cell 92:279-289.

Thomas CG, Miller AJ, Westbrook GL (2006) Synaptic and extrasynaptic NMDA receptor NR2 subunits in cultured hippocampal neurons. J Neurophysiol 95:1727-1734.

Tovar KR, Westbrook GL (1999) The incorporation of NMDA receptors with a distinct subunit composition at nascent hippocampal synapses in vitro. J Neurosci 19:4180-4188.

Vogt K, Mellor J, Tong G, Nicoll R (2000) The actions of synaptically released zinc at hippocampal mossy fiber synapses. Neuron 26:187-196.

Weitlauf C, Honse Y, Auberson YP, Mishina M, Lovinger DM, Winder DG (2005) Activation of NR2A-containing NMDA receptors is not obligatory for NMDA receptor-dependent long-term potentiation. J Neurosci 25:8386-8390.

Wenzel A, Scheurer L, Khnzi R, Fritschy JM, Mohler H, Benke D (1995) Distribution of NMDA receptors subunit proteins NR2A, 2B, 2C and 2D in rat brain. NeuroReport 7:45-48.
Westbrook GL, Mayer ML (1987) Micromolar concentrations of $\mathrm{Zn}^{2+}$ antagonize NMDA and GABA responses of hippocampal neurons. Nature 328:640-643.

Williams K (1993) Ifenprodil discriminates subtypes of the N-methyl-Daspartate receptor: selectivity and mechanisms at recombinant heteromeric receptors. Mol Pharmacol 44:851-859.

Williams K (1996) Separating dual effects of zinc at recombinant N-methylD-aspartate receptors. Neurosci Lett 215:9-12.

Xie X, Smart TG (1994) Modulation of long-term potentiation in rat hippocampal pyramidal neurons by zinc. Pflügers Arch 427:481-486.

Yamada Y, Iwamoto T, Watanabe Y, Sobue K, Inui M (2002) PSD-95 eliminates Src-induced potentiation of NR1/NR2A-subtype NMDA receptor channels and reduces high-affinity zinc inhibition. J Neurochem 81:758-764.

Zorumski CF, Mennerick S, Que J (1996) Modulation of excitatory synaptic transmission by low concentrations of glutamate in cultured rat hippocampal neurons. J Physiol (Lond) 494:465-477. 